\title{
Unexpected Effects of Pigeon-Peas (Cajanus cajan) In the RESTORATION OF RUPESTRIAN FIELDS ${ }^{1}$
}

\author{
Efeito Inesperado do Feijão-Guandu (Cajanus cajan) na Restauração de Campos Rupestres
}

\author{
HILÁRIO, R.R. ${ }^{2,3}$, CASTRO, S.A.B. ${ }^{4}$, KER, F.T.O. ${ }^{2}$ and FERNANDES, G. ${ }^{2}$
}

\begin{abstract}
Several degraded areas can be found along the Highway MG-010 that crosses the Espinhaço Mountain Biosphere Reserve in the Brazilian state of Minas Gerais. Restoration by planting the legume Cajanus cajan was implemented in some of these areas. The present study compares plant species richness, diversity, abundance, equitability, similarity, and soil composition between restored and non-restored areas, in an attempt to evaluate the effectiveness of the use of $C$. cajan in the restoration process in the mountain environment. Each treatment (restored and non-restored) had four sampling areas, each with three $300 \mathrm{~m}^{2}$ plots. We counted and identified every individual plant found within these plots. We also collected soil from the superficial layer $(0-10 \mathrm{~cm})$ of each sampling area in both treatments. The areas where C. cajan was planted revealed lower species richness, diversity, and plant abundance. The soil of these areas also contained higher levels of Phosphorus and Magnesium. Plant equitability and similarity between plots and other soil components ( $\mathrm{pH}$, Nitrogen, Aluminum, Calcium, Potassium, H+A1, sum of bases - SB, cation exchange capacity - CTC, base saturation - V\%, aluminum saturation - M\%) did not differ between the two treatments. Contrary to the expectations, soil enhancement in the quartzitic soil poor in nutrients in the rupestrian fields can facilitate the invasion by exotic plants, which are not adapted to the lack of nutrients. As it appears, the use of $C$. cajan in restoration projects represents a mistake and future restoration plans should avoid the use of exotic species, given that they may cause negative effects on the native plant community, as demonstrated here in the rupestrian fields.
\end{abstract}

Keywords: environmental impacts, restoration ecology, Serra do Cipó, tropical mountains.

RESUMO - Várias áreas degradadas podem ser encontradas ao longo da rodovia MG-O10, que corta a Reserva da Biosfera da Cadeia do Espinhaço, em Minas Gerais, Brasil. Algumas dessas áreas foram restauradas através do plantio da leguminosa Cajanus cajan. O presente trabalho compara a riqueza, diversidade, abundância, equitabilidade e similaridade da comunidade de plantas, e composição do solo de áreas degradadas restauradas e não restauradas, a fim de avaliar a efetividade do uso de C. cajan no processo de restauração. Cada tratamento (áreas restauradas e não-resturadas) teve quatro áreas amostrais, as quais, por sua vez tiveram três parcelas de $300 \mathrm{~m}^{2}$. Em cada parcela, todos os individuos de planta foram contados e identificados. Além disso, foi coletado o solo da camada superficial em todas as quatro áreas amostrais de ambos os tratamentos. As áreas onde C. cajan foi plantado apresentaram menores riqueza, diversidade e abundância de plantas. O solo dessas áreas também apresentou níveis mais altos de Fósforo e Magnésio. Equitabilidade e similaridade e outros componentes do solo (pH, Nitrogênio, Aluminio, Cálcio, Potássio, H+Al, Soma de Bases - SB, Capacidade de Troca Catiônica- CTC, Saturação de Bases - V\%, Saturação de Aluminio - M\%) não variaram entre os tratamentos. Ao contrário do esperado, o enriquecimento dos solos quartzíticos pobres em nutrientes dos campos rupestres pode facilitar a invasão desses ambientes por espécies exóticas não adaptadas à falta de nutrientes. Portanto, foi concluido que a restauração com o uso de C. cajan foi um equivoco e que os próximos planos de restauração nesse tipo de ambiente devem evitar o uso de espécies exóticas, já que o uso destas pode terum efeito pior do que manter a área sem nenhuma ação.

Palavras-chave: impactos ambientais, montanhas tropicais, reabilitação, Serra do Cipó.

Recebido para publicação em 22.4.2010 e aprovado em 14.4.2011.

2 Dep. de Biologia Geral, Instituto de Ciências Biológicas, Universidade Federal de Minas Gerais - UFMG, Caixa Postal 486, 30161-970 Belo Horizonte-MG, Brasil, <gw.fernandes@gmail.com>; 3 Dep. de Sistemática e Ecologia, Centro de Ciências Exatas e da Natureza, Universidade Federal da Paraíba - UFPB, Cidade Universitária, 58051-900 João Pessoa-PB, Brazil, <renatohilario@gmail.com>; ${ }^{4}$ Dep. de Botânica, Instituto de Ciências Biológicas, UFMG, $<$ silvana.abcastro@gmail.com>

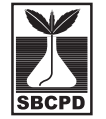

Planta Daninha, Viçosa-MG, v. 29, n. 4, p. 717-723, 2011 


\section{INTRODUCTION}

The rupestrian fields of the southeastern Brazil are composed of a mosaic of vegetation types, from which we barely know the number of species and some natural history. The steady increase in human activity within this region has impacted this ecosystem in recent decades. Impacts originating from mining, road construction, pasture establishment, tourism, and periodic fires, have been the main source of soil erosion, species extinction, and alien species invasion (Viana et al., 2005; Barbosa \& Fernandes, 2008; Barbosa et al., 2010).

The Brazilian National System of Conservation Units (SNUC, Law 9.985 of 18/ $7 / 2000)$ defines the meaning of the term environmental restoration as "restoring degraded ecosystems or wild populations to as near as possible to their original condition". However, most initiatives to restore degraded areas have been using methods that do not follow this definition strictly. In most cases, exotic species are used with consequences to ecosystem processes and functioning not fully evaluated.

The highway MG010 connects the municipalities of Lagoa Santa and Conceição do Mato Dentro, crossing the Environmental Protection Area (APA) Morro da Pedreira and being adjacent to the Serra do Cipó National Park. This highway was restored in 2004 and the pigeon pea, Cajanus cajan (Fabaceae), was used to facilitate the succession process. C. cajan is an annual or semi-perennial shrub widely used to restore degraded areas and renew pasture (Beltrame \& Rodrigues, 2007). The species has its origins in India (Provazi et al., 2007) and possesses a deep ramified root that enables its survival throughout longer periods of water stress (Alcântara et al., 2000). The explanation mostly used to justify the use of this alien species in reclamation has been that the species is capable of increasing soil fertility, due to its association with beneficial microorganisms, such as Rhyzobium and mycorrhiza (Olsen \& Habte, 1995). Ultimately, better nutrient mobilization would enhance plant growth and performance, hence leading to faster and larger vegetation cover.
The technical procedure 13030 from ABNT (Brazilian Association of Technical Norms and Procedures) of 1998 explicitly recommends the exclusive use of local plant species in restoration programs (ABNT, 1998). Ignoring this fact, environmental agencies have broadly allowed the use of exotic species, despite awareness of the impacts of invasive species on local flora and associated fauna.

Many alternatives have been proposed to restore the degraded areas in order to propagate well adapted native species of the rupestrian fields (Medina \& Fernandes 2007; Negreiros et al., 2008, 2009). In spite of the scientific arguments that the use of $C$. cajans could trigger several ecosystem problems and that a claim existed for the use of native species, the exotic species was used to restore some degraded areas along the margins of Highway MG 10 following the argument that, due to the proximity of the rainy period, erosion could be a worse problem (Ribeiro et al., 2005). The environmental agencies involved allowed the use of a mix of species containing many exotic species that were spread into the region by hydro-seeding, when previous studies had advised the use of only native species (Ribeiro et al., 2005). The justification to use $C$. cajan was based on its potential to enhance the succession process due to the plant's nitrogen fixation capacity and the ability to create shade for other plants.

However, several years after its introduction, casual observations indicated that $C$. cajan may not behave as expected since it was neither shadowing other species nor providing a vegetative cover to the eroded areas. Instead, C. cajan was suspected of negatively affecting the entire community of plants that inhabit the highly diverse rupestrian fields in Serra do Cipó, and seedling of the exotic species were observed outside the degraded areas, spreading into the already fragile and unique mountain vegetation. Therefore, the goal of this study is to provide empirical data on the effects of using C. cajan in reclamation projects by comparing plant species richness, diversity, equitability, similarity, and abundance and soil composition between restored and nonrestored areas. 


\section{MATERIAL AND METHODS}

This study was carried in Serra do Cipó, located in the southernmost part of the Espinhaço mountain chain, in the central part of the Brazilian State of Minas Gerais. The region is characterized by mesothermic climate, with dry winters and wet summers. Mean temperature ranges from 17.4 to $19.8{ }^{\circ} \mathrm{C}$, and annual precipitation averages around $1.500 \mathrm{~mm}$ (Giulietti et al., 1997). Elevation at the studied sites averages 1100 meters.

We evaluated degraded areas between the kilometers 102 and 106 of the highway MG-

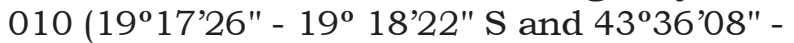
$\left.43^{\circ} 36^{\prime} 32 \mathrm{~W}\right)$. All monitored areas were located from five to fifty meters from the road. Out of the eight chosen areas, four were previously restored through the planting of $C$. cajan, while the other four areas were considered control plots (non-restored degraded areas of similar impact). Restored and non-restored areas were located at a minimum of $100 \mathrm{~m}$ to a maximum of $3.5 \mathrm{~km}$ apart. In each of these areas, three plots of $5 \times 5$ meter (totalizing $300 \mathrm{~m}^{2}$ for each treatment) were randomly chosen. All plant individuals (except grasses) within the plots were counted and identified. We analyzed the number of plant species (richness), plant diversity (Shannon index) (Niklaus et al., 2001), and equitability considering the number of individuals and species in the sum of the plots. In addition, we compared the area similarity (comparing plots through Jaccard index) (Ricklefs, 2003) within both treatments.

Although C. cajan density within the restored areas was measured, it was decided to remove this species from the comparison with non-restored areas in order to identify more clearly the effects of the use of this species on the plant community. To test the influence of $C$. cajan on soil nutrients, we collected one composite soil sample per area (totalizing eight samples). Each sample was composed of soil from the superficial layer (maximum depth: $10 \mathrm{~cm}$ ) of ten randomly chosen points within each area (Negreiros et al., 2008). We measured the amount of Nitrogen, Phosphorus, Magnesium, pH, Calcium, Aluminum, base saturation, Aluminum saturation, cation exchange capacity (CEC), and sum of bases (SB) to observe whether $C$. cajan positively improved soil nutritional quality.

As some data did not present normal distribution and variance homogeneity, we used the Mann-Whitney test to compare diversity, species richness, equitability, plant abundance, and soil traits. To evaluate the influence of Phosphorus and Magnesium on the plant abundance and species richness we used a Pearson correlation (Zar, 1999).

\section{RESULTS AND DISCUSSION}

Cajanus cajan density within the restored areas was $4.7 \pm 3.0$ individuals $\mathrm{m}^{2}$. The older individuals of $C$. cajan reached the height of $1.8 \mathrm{~m}$. Of the 88 plant species found colonizing the restored and non-restored areas in this study, $61(70 \%)$ were found only in nonrestored areas, $13(14 \%)$ were found only in restored areas, while $14(16 \%)$ were common to both areas. Species richness and plant abundance were 2.5 fold higher in the nonrestored areas. Likewise, diversity was 1.5 fold higher in areas where the C. cajan was not planted. Equitability did not differ significantly between the restored and non-restored sites (Table 1). Similarity was small and varied from 0 to 0.1 in restored sites while it varied from 0 to 0.2 in non-restored sites $(U=16.0$; $p=0.7488$ ).

The amount of Phosphorus ( $\mathrm{U}=0.5$; $\mathrm{p}=0.030)$ and Magnesium $(\mathrm{U}=0 ; p=0.0209)$, two important soil components and quality indicators, were 4.5 fold greater in the areas where the $C$. cajan was planted, indicating the importance of this species to soil fertilization. On the other hand, none of the other soil components analyzed differed statistically between the two treatments (Table 2).

When only the areas restored with $C$. cajan were analyzed, we observed that there was a strong positive correlation between the concentration of Phosphorus in the soil and plant abundance $(\mathrm{r}=0.986 ; p=0.0145)$. However, Phosphorus concentration in the soil did not correlate with species richness in these areas $(\mathrm{r}=0.098 ; p=0.9023)$. The amount of Magnesium did not correlate either with plant abundance $(\mathrm{r}=0.308 ; p=0.6921)$, or species richness $(\mathrm{r}=0.789 ; p=0.2109)$. 
Table 1 - Total species richness, diversity $\left(\mathrm{H}^{\prime}\right)$, mean equitability in the areas, plant abundance, and mean similarity between areas for restored and non-restored areas

\begin{tabular}{|l|c|c|c|}
\hline & $\begin{array}{c}\text { Area restored with } \\
\text { C. cajan }\end{array}$ & Non-restored area & $\begin{array}{c}\text { Mann-Whitney } \\
(\alpha=0,05)\end{array}$ \\
\hline Species richness & 27 & 75 & $\mathrm{U}=0.00 ; p=0.0209$ \\
\hline Diversity & 2.58 & 3.76 & $\mathrm{U}=0.00 ; p=0.0209$ \\
\hline Equitability & $0.82 \pm 0.08$ & $0.85 \pm 0.06$ & $\mathrm{U}=6.50 ; p=0.6650$ \\
\hline Similarity & $0.10 \pm 0.08$ & $0.07 \pm 0.04$ & $\mathrm{U}=16.0 ; p=0.7488$ \\
\hline Plant abundance & 93 & 245 & $\mathrm{U}=0.00 ; p=0.0209$ \\
\hline
\end{tabular}

Table 2 - Mean values and standard error of each nutrient and $\mathrm{pH}$ in soil samples taken from restored and non-restored areas

\begin{tabular}{|c|c|c|c|}
\hline & $\begin{array}{l}\text { Area restored with } \\
\text { C. cajan }\end{array}$ & Non-restored area & $\begin{array}{c}\text { Mann-whitney } \\
(\alpha=0,05)\end{array}$ \\
\hline $\mathrm{pH}\left(\mathrm{H}_{2} \mathrm{O}\right)$ & $6.39 \pm 1.31$ & $5.46 \pm 0.68$ & $\mathrm{U}=4 ; \mathrm{p}=0.2482$ \\
\hline $\mathrm{N}\left(\right.$ dag kg $\left.{ }^{-1}\right)$ & $0.015 \pm 0.06$ & $0.017 \pm 0.05$ & $\mathrm{U}=6 ; \mathrm{p}=0.4945$ \\
\hline $\mathrm{P}\left(\mathrm{mg} \mathrm{dm}^{-3}\right)$ & $2.28 \pm 1.04$ & $0.50 \pm 0.29$ & $\mathrm{U}=0.5 ; \mathrm{p}=0.030$ \\
\hline $\mathrm{K}\left(\mathrm{mg} \mathrm{dm}^{-3}\right)$ & $30.0 \pm 16.3$ & $16.25 \pm 7.54$ & $\mathrm{U}=3 ; \mathrm{p}=0.1489$ \\
\hline $\mathrm{Ca} 2+\left(\mathrm{cmolc} \mathrm{dm}^{-3}\right)$ & $1.55 \pm 1.42$ & $0.47 \pm 0.66$ & $\mathrm{U}=3 ; \mathrm{p}=0.1489$ \\
\hline $\mathrm{Mg} 2+\left(\mathrm{cmol}_{\mathrm{c}} \mathrm{dm}^{-3}\right)$ & $0.18 \pm 0.15$ & $0.04 \pm 0.01$ & $\mathrm{U}=0 ; \mathrm{p}=0.0209$ \\
\hline $\mathrm{Al} 3+\left(\mathrm{cmol}_{\mathrm{c}} \mathrm{dm}^{-3}\right)$ & $0.05 \pm 0.06$ & $0.36 \pm 0.37$ & $\mathrm{U}=4 ; \mathrm{p}=0.2482$ \\
\hline $\mathrm{H}+\mathrm{Al}\left(\mathrm{cmol}_{\mathrm{c}} \mathrm{dm}^{-3}\right)$ & $1.15 \pm 0.98$ & $1.60 \pm 0.65$ & $\mathrm{U}=6 ; \mathrm{p}=0.5637$ \\
\hline $\mathrm{SB}\left(\mathrm{cmol}_{\mathrm{c}} \mathrm{dm}^{-3}\right)$ & $1.80 \pm 1.37$ & $0.56 \pm 0.65$ & $\mathrm{U}=2 ; \mathrm{p}=0.0833$ \\
\hline$(\mathrm{CEC})\left(\mathrm{cmol}_{\mathrm{c}} \mathrm{dm}^{-3}\right)$ & $1.85 \pm 1.32$ & $0.91 \pm 0.51$ & $\mathrm{U}=3 ; \mathrm{p}=0.1489$ \\
\hline $\mathrm{V}(\%)$ & $59.97 \pm 32.86$ & $22.88 \pm 17.99$ & $\mathrm{U}=2 ; \mathrm{p}=0.0833$ \\
\hline $\mathrm{M}(\%)$ & $4.90 \pm 5.77$ & $44.75 \pm 35.99$ & $\mathrm{U}=3 ; \mathrm{p}=0.1489$ \\
\hline
\end{tabular}

$\mathrm{SB}$ - sum of bases; CEC - cation exchange capacity; V - base saturation; M - aluminun saturation.

The data presented here shows that the restoration program using the exotic species C. cajan influenced negatively species richness, plant abundance, and consequently, plant diversity in the speciose rupestrian fields of Serra do Cipó. These results contradict the idea that increasing soil fertility is a key element in restoration programs (Negreiros et al., 2009). Beltrame \& Rodrigues (2007) stated that the use of $C$. cajan in restoring programs at forest sites have positive effects by enhancing the structural progression towards advanced stages of succession. Perhaps, the use of alien sun-plants in forest ecosystems would have reduced impacts in the community, as it is expected that these species became extinct as the native trees grow. However, this is not the case of the rupestrian fields where soils are nutrient poor (Ribeiro \& Fernandes, 2000; Benites et al., 2003; Negreiros et al., 2008, 2009), therefore making the use of an exotic species in this environment a mistake. In addition, $C$. cajan seeds remain in the environment due to its incorporation into the local seed bank; thus, increasing the biological invasion risk to this fragile mountain ecosystem. Casual observations indicate that under larger density, C. cajan imposes difficulties to the establishment of native plants by natural germination.

Addition of nutrients, especially phosphorus and nitrogen, and elimination of the toxicity caused by aluminum in low fertile environments can lead to rapid population 
growth of some species or invasion by others (Hobbs \& Huenneke, 1992; Negreiros et al., 2009). Barbosa et al. (2010) have shown that soil improvement caused by road paving made the nutrient-poor soils less habitable for native species, while the same process made the soils suitable for colonization by invasive species. Under such a scenario, C. cajan presents an elevated invasive potential, given that this species benefits from soil improvement, disturbances caused by the road paving process, and lack of competition with the native species.

Beltrame \& Rodrigues (2007) found soils richer in nitrogen and organic matter in areas where C. cajan was planted. Although the amount of organic matter was not analyzed in the present study, the amount of nitrogen between the two treatments did not differ statistically. The quantity of magnesium found in this study was lower than that reported by Marques et al. (2002) and Benites et al. (2003) for Serra do Cipó.

The level of Phosphorus found in the restored areas was higher then the level reported by Marques (2002) and Negreiros et al. (2009), while the values found in non-restored areas were similar to those reported by Negreiros et al. (2008). The higher amount of Phosphorus in the soil must also be related to the elevated litter formation in the areas where C. cajan was planted. The disturbance of a system through species introduction, biomass input, or manuring can lead to higher levels of Phosphorus mineralization due to an increase in the microbial activity (Gatiboni et al., 2008). In addition, restoring procedures are generally associated with calcium and phosphate input (Embrapa, 1992), which can also explain the higher amount of phosphorus in the areas where C. cajan was planted. After fertilization, the inorganic forms of phosphorus increase due to its accumulation in the soil (Grant et al., 2001; Gatiboni et al., 2008).

The values of $\mathrm{Ca}^{2+}$ in both areas were higher than those reported by Ribeiro \& Fernandes (2000) and Negreiros et al. (2008) for some areas of rupestrian fields in Serra do Cipó. Barbosa \& Fernandes (2010) also found high levels of $\mathrm{Ca}^{2+}$ in areas adjacent to highway MG-010. The phenomenon was explained by the paving process, which uses a substance rich in $\mathrm{CaCO}_{3}$ that would promote an increase in $\mathrm{pH}$ along the road side. In fact, we found high $\mathrm{pH}$ levels in both treatments. The high level of $\mathrm{Ca}^{2+}$ can also be associated to the addition of $\mathrm{Ca}^{2+}$ in the areas, although the treatments did not differ statistically. The values of $\mathrm{Al}^{3+}$ found in this study are lower than the ones found for other studies in the same region (Ribeiro \& Fernandes, 2000; Benites et al., 2003; Negreiros et al., 2008).

The increase in phosphorus, magnesium, and $\mathrm{pH}$, as well as the smaller amount of $\mathrm{Al}^{3+}$ indicate that the soils were largely modified during the paving process. Rupestrian field soils are generally acidic, poor in nutrients, and contain high Aluminum saturation values due to geological and geomorphological conditions (Benites et al., 2003; Negreiros et al., 2008). Despite the higher concentration of phosphorus, the presence of $C$. cajan influenced negatively the colonization and establishment of plant community of the rupestrian fields in Serra do Cipó. Even if the nutrient increase that resulted from the presence of $C$. cajan positively influenced plant abundance, it would also affect species diversity. Fertilization can enhance the growth rate of plants during restoration processes, but can also promote competitive exclusion of some species (Lawrence, 2003). Indeed, Tilman (1987) found a negative correlation between species richness and soil fertilization while Negreiros et al. (2009) stated that soil improvement through human intervention in the rupestrian fields favors exotic species in detriment of native ones.

Natural tropical ecosystems are formed by numerous types of vegetation in which species composition and selective pressures imposed by both, biotic and abiotic factors, may be singular. Restoration must take into account previous knowledge and idiosyncrasies of each vegetation and site. The perception that cocktails of species can be widely used in restoration and that the use of exotic Fabaceae does not represent risks to the succession process is misleading. The observations we present here, together with those reported by Negreiros et al. (2008, 2009), make it clear that the cocktails of exotic species and restoration programs using common practices that enhance soil fertilization cannot be applied to 
nutritionally and water stressed environments. The introduction of exotic species is one of the main causes of the current mass extinction of species (Mittermeier et al., 2005) and a threat to the highly diverse mountain ecosystems in Serra do Cipó.

In conclusion, the use of $C$. cajan, the pigeon peas, to initiate the restoration process in degraded areas of rupestrian fields is a misguided initiative. Although equitability, similarity between plots, and some soil components did not vary between treatments, the restoration project reduced plant diversity and abundance in the areas examined. C. cajan positively influenced the amount of phosphorus and magnesium in restored area soils, but the increase of these nutrients in the soil imposes negative effects on the flora, instead of enhancing plant succession. Deeper understanding of the role of commonly used practices and exotic species in the restoration of Brazilian vegetation is urgently needed because tropical vegetations present different species composition structure and functional properties.

\section{ACKNOWLEDGMENTS}

We are grateful to the Programa de Pós-graduação em Ecologia, Conservação e Manejo da Vida Silvestre/UFMG. We also would like to thank the Reserva Natural Vellozia for logistical support; to C. Rankine, D. Negreiros and N. Barbosa for suggestions and commentaries. We also thank the support provided by FAPEMIG (CRA 465/07, 122/07, APQ-01278-08) and CNPq (309633/2007-9).

\section{LITERATURE CITED}

ALCÂNTARA, F. A. et al. Adubação verde na recuperação da fertilidade de um Latossolo vermelho-escuro degradado. Pesq. Agropec. Bras., v. 35, n. 2, p. 277-288, 2000.

ASSOCIAÇÃO BRASILEIRA DE NORMAS TÉCNICAS ABNT. NBR 13030: Elaboração e apresentação de projetos de reabilitação de áreas degradadas pela mineração. Rio de Janeiro: 1999. 5 p.

BARBOSA, N. U. et al. Distribution of non-native invasive species and soil properties in proximity to paved roads and unpaved roads in a quartzitic mountainous grassland of southeastern Brazil (rupestrian fields). Biol. Invasions, v. 12, n. 11, p. $3745-3755,2010$.
BARBOSA, N. U.; FERNANDES, G. W. A destruição do jardim. Sci. Am. Brasil, v. 79, p. 82-84, 2008

BELTRAME, T. P.; RODRIGUES, E. Feijão guandu (Cajanus cajan L. Millsp.) na restauração de florestas tropicais. Seminário Ci. Agr., v. 28, n. 1, p. 19-28, 2007

BENITES, V. M. et al. Solos e vegetação nos complexos rupestres de altitude da Mantiqueira e do Espinhaço. Flor. Amb., v. 10, n. 1, p. 76-84, 2003.

EMPRESA BRASILEIRA DE PESQUISA AGROPECUÁRIA - EMBRAPA. Revegetação de solos degradados. 1992. 9 p. (Comunicado Técnico)

GATIBONI, L. C. et al. Fósforo da biomassa microbiana e atividade de fosfatases ácidas durante a diminuição do fósforo disponível no solo. Pesq. Agropec. Bras., v. 43, n. 8, p. 1085-1091, 2008 .

GIULIETTI, A. M. et al. Espinhaço range region, Eastern Brazil. In: DAVIS, S. D. et al. (Eds.). Centres of plant diversity: the Americas. Oxford: World Wide Fund For Nature, 1997. p. 397-404

GRANT, C. A. et al. A importância do fósforo no desenvolvimento inicial da planta. Inf. Agropec., n. 95, p. 1-16, 2001.

HOBBS, R. H.; HUENNEKE, L. F. Disturbance, diversity, and invasion: implications for conservation. Conserv. Biol. v. 6, n. 3 , p. $324-337,1992$

LAWRENCE, D. The response of tropical tree seedlings to nutrient supply: meta-analysis for understanding a changing tropical landscape. J. Trop. Ecol., v. 19, n. 3, p. 239-250, 2003.

MARQUES, A. R. et al. Distribution of adult male and female Baccharis concinno (Asteraceae) in the rupestrian fields of Serra do Cipó, Brazil. Plant Biol., v. 4, p. 94-103, 2002.

MEDINA, B. M. O.; FERNANDES, G. W. The potential of natural regeneration of rocky outcrop vegetation on rupestrian field soils in "Serra do Cipó", Brazil. R. Bras. Bot., v. 30, n. 4, p. 665-678, 2007.

MITTERMEIER, R. A. et al. Hotspots revisitados. Belo Horizonte: Conservação Internacional, 2005. 15 p.

NEGREIROS, D. et al. Caracterização da fertilidade dos solos de quatro leguminosas de campos rupestres, Serra do Cipó, MG, Brasil. J. Soil Sci. Plant Nutr., v. 8, n. 4, p. 30-39, 2008.

NEGREIROS, D. et al. Seedling growth and biomass allocation of endemic and threatened shrubs of rupestrian fields. Acta Oecol., v. 35, n. 2, p. 301-310, 2009. 
NIKLAUS, P. A. et al. A long-term field study on biodiversity $\mathrm{X}$ elevated $\mathrm{CO}^{2}$ interactions in grassland. Ecol. Monogr., v. 71, n. 3 , p. $341-356,2001$

OLSEN, T.; HABTE, M. Mycorrhizal inoculation effect on nodulation and $\mathrm{N}$ accumulation in Cajanus cajan at soil $\mathrm{P}$ concentrations sufficient or inadequate for mycorrhiza-free growth. Mycorrhiza, v. 5, n. 6, p. 395-399, 1995

PROVAZI, M. et al. Botanical description of selected pigeonpea pure lines. R. Bras. Zootecn., v. 36, n. 2, p. 328-334, 2007

RIBEIRO, K. T. et al. Ocupação por Brachiaria spp. (Poaceae) no Parque Nacional da Serra do Cipó e infestação decorrente da obra de pavimentação da rodovia MG-010 na APA Morro da Pedreira. Minas Gerais. In: SIMPÓSIO BRASILEIRO DE ESPÉCIES INVASORAS, 1., 2005, Brasília. Anais... Brasília: 2005. p. 1-17.
RIBEIRO, T. K.; FERNANDES, G. W. Patterns of abundance of a narrow endemic species in a tropical and infertile montane habitat. Plant Ecol., v. 147, n. 2, p. $205-218,2000$.

RICKLEFS, R. E. A economia da natureza. 5.ed. Rio de Janeiro: Guanabara Koogan, 2003. 503 p.

TILMAN, D. Secondary succession and the pattern of plant dominance along experimental nitrogen gradients. Ecol. Monogr., v. 57, n. 3, p. 190-214, 1987.

VIANA, L. R. et al. Ecological road threatens endemic Brazilian plant with extinction. Plant Talk, v. 41 n.15, p. 15, 2005.

ZAR, J. H. Biostatistical analysis. 4. ed. New Delhi: Pearson Education, 1999. 663 p. 